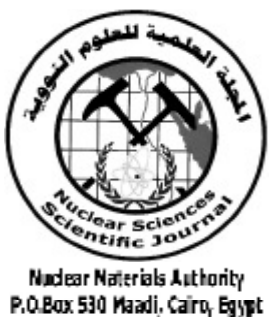

ISSN 2314-5609

Nuclear Sciences Scientific Journal

$5,49-67$

2016

http://www.ssnma.com

\title{
MINERALOGY AND RADIOACTIVITY OF WADI HANGALIYA STREAM SEDIMENTS, SOUTH EASTERN DESERT OF EGYPT
}

\author{
GEHAD M. MANSOUR; ABDEL ALEEM A. ABU DIAB and ANAS M. EL SHERIF \\ Nuclear Materials Authority, P. O. Box 530, El Maadi Cairo, Egypt
}

\begin{abstract}
The present paper sheds some light on the mineralogy and radioactivity of stream sediments in Wadi Hangaliya, South Eastern Desert of Egypt. Therefore, eighteen stream sediments have been examined. The wadi is surrounded by several rock units; metavolcanics, mafic-ultramafic rocks and younger granites. The grain size analyses reveal that stream sediments are immature, about $33 \%$ and $28 \%$ of the sediments lie in the very coarse sand and coarse sand fractions, respectively. About $72 \%$ of the sediments are poorly sorted. It attains average heavy 5.82 and $2.33 \%$ for both fine and very fine sand size fractions, respectively. The recorded heavy minerals include opaques with an average content of $13.3 \%$ and $14.6 \%$ in the fine and very fine sand fractions, respectively. The opaques are dominated by magnetite, ilmenite and hematite. The non-opaques include zircon, rutile, staurolite, sillimanite, titanite, amphiboles, pyroxenes, epidotes, apatite, garnet, barite and tourmaline. The preliminary estimation of visible gold content in sand fraction giving an average of $1.135 \mathrm{~g} / \mathrm{t}$ Au. Gold was recorded in $72 \%$ of the studied samples. Ground spectroscopic measurements and aero-radiometric previous work of the hinterlands show weak radioactivity; increasing slightly to the west portion of Wadi Hangaliya. The increase in radioactivity may be attributed to Gabal Nugrus younger granite. The radioactive minerals include; monazite, metamict zircon and thorite. In addition, the presence of ${ }^{40} \mathrm{~K}$ in the potash feldspars and micas of the light fraction. Thus, the weak radioactivity of Wadi Hangaliya makes it suitable for gold extraction field industry.
\end{abstract}

\section{INTRODUCTION}

The area of Wadi Hangaliya is occupying an ancient gold mining activity and there are remnant of ancient houses in the area which the wadi cuts Gabal Nugrus (western part of the wadi). The present work sheds light on the mineralogical, sedimentological and radiometric characteristics of stream sediments in Wadi Hangaliya. This work is also aiming to present information about the estimation of gold in the sand size fractions.

\section{GEOLOGIC SETTING}

The geologic settings of the study area are divided into two major groups separated by a low angle thrusting (Nugrus thrust) and intruded by the late younger granitoids, i.e. Gabal Nugrus (Fig. 1a). The structurally lower group comprises the Migif-Hafafit gneisses and associated rocks (El Ramly et al., 1993). This group is characterized by medium grade metamorphism and complex deformation. The second group, known as Ghadir Group, tectonically overlies the first group and is characterized by relatively low metamorphic grade and simpler deformation (El Bayoumi and Greiling, 1984). The two groups are separated by a major thrust fault known as the Nugrus thrust (Fig. 1a). 


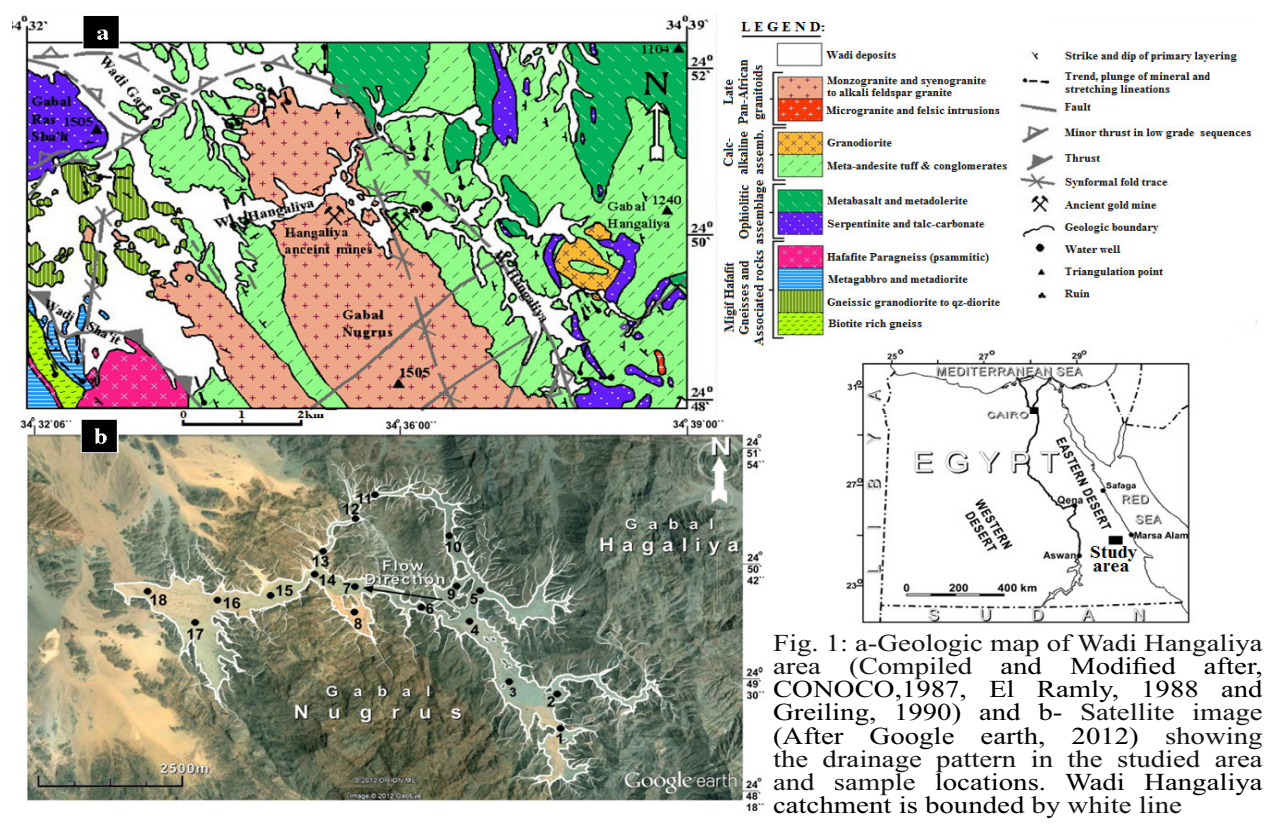

Wadi Hangaliya runs through several lithostratigraphical units affected by several metamorphic events and plutonic cycles. The country rocks of Wadi Hangaliya (Fig. 1b) include ophiolitic assemblage (consists of mafic-ultramafic fragments set in metasediment matrix); arc metavolcanics composed of calcalkaline assemblage include granodiorite and meta-andesite tuffs and conglomerates, latePan African granites and post-granite dykes and veins (El Gaby et al., 1988).

Wadi Hangaliya crosses metavolcanics at its eastern extremity represented by massive basalt to meta-basalt and meta-dolerite with serpentinites. At the western extremity of Wadi Hangaliya, there are several exposures of heterogeneous pink-coloured granites that range in composition from syano- to monzogranite to alkali feldspar granite. Gabal Nugrus has elongation in NW direction. It contains itself elongated strips of arc metavolcanic rocks (El Feky, 2000 and El Feky et al., 2004). The post granite dykes are represented by sets of felsic to basic dykes and quartz veins. The Holocene terraces at Wadi Hangaliya are more common at western part and partly covered by windblown sand. The main wadi and its tributaries are filled with fragments of extremely variable sizes ranging from very fine up to boulder sizes (Fig. 2).

\section{METHODOLOGY}

\section{Field Spectrometry Survey and Sampling}

Spot ground gamma-ray spectrometry survey was carried out in the field along Wadi Hangaliya. Portable GS-256 scintillometer was used for continuous monitoring and recording of any one of the four selected energy regions, $\mathrm{TC}, \mathrm{eTh}, \mathrm{eU}$ and $\mathrm{K}$; or the sequential measurements of the four channels.

Careful selection of samples was carried with the documentation of their locations using a modern global positioning system tool (GPS), followed by plotting on recent satellite image (Google Earth, 2012, Fig. 1b). Eighteen sediment samples were collected from the main course of the wadi. These sam- 


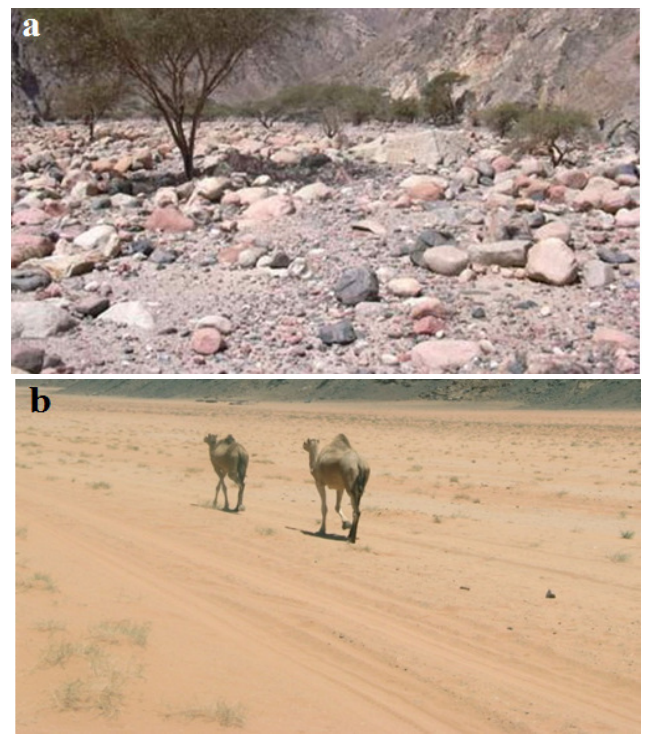

Fig. 2: Variation in development of Wadi Hangaliya sediments; immature upstream fanglomerates (a) and fine sands in the downstream (b)

ples were obtained by digging boreholes with depth ranging from 30 to $70 \mathrm{~cm}$ after stripping off the surface windblown sand layer. The average weight of each sample is about $10 \mathrm{~kg}$. The coarser grains were removed in the field. The grains $>4.0 \mathrm{~mm}$ size were excluded by sieving.

\section{Laboratory Techniques}

The collected samples were subjected to preparation procedures in the Nuclear Materials Authority (NMA) Labs., Egypt. The studied samples are quartered using Jhon's Splitter to obtain a representative samples. In order to have an idea about some sedimentological characteristics of the collected stream sediment samples. They are subjected to mechanical analysis. About $100 \mathrm{~g}$ for each representative sample are subjected to dry sieving technique using three standard screens with aperture diameter of $0.25,0.125$ and $0.63 \mathrm{~mm}$. In addition, bromoform (specific gravity of $2.85 \mathrm{gm} / \mathrm{cm}^{3}$ ) is used to separate the total heavy minerals content. Most of mag- netite is separated from each heavy fraction using a hand magnet with suitable strength. The magnetite-free fractions are magnetically fractionated using the Frantz isodynamic magnetic separator Model L-1 at 0.08, 0.2, $0.5,1.0$ and $1.5 \mathrm{~A}$.

0.08A magnetic fractions separates remaining of titano-magnetite. $0.2 \mathrm{~A}$ magnetic fraction contains most of ilmenite $(>90 \%)$, garnet $(80 \%)$ and nearly $15 \%$ green silicates. $0.5 \mathrm{~A}$ magnetic fraction contains all the remaining ilmenite, considerable amount of altered ilmenite $(30 \%)$ and garnet $(15 \%)$; also monazite, chromite and minor amount of green silicates. 1.5A magnetic fraction contains about $75 \%$ of leucoxene, traces of garnet and chromite. More than $65 \%$ of the paramagnetic green silicate minerals (pyroxenes, amphiboles and epidotes) and most of monazite $(85 \%)$ are present. $1.5 \mathrm{~A}$ non-magnetic fraction contains about $\geq 95 \%$ rutile, with $\geq 95 \%$ zircon and trace amount of green silicates (Farid, 2005).

In addition, wet tabling technique is used to primarily estimation of the visible gold content in the studied samples. Therefore, eighteen bulk samples weighed $0.5 \mathrm{~kg}$ for each are used to recovery gold by a simple mechanical panning technique using a full size Wilfley shaking table at Coastal Research Institute, Alexandria, Egypt. This technique has been described by Taggart (1956), Antweiler and Love (1967) and English et al. (1987) to obtain high purity of native gold, silver, mercury, amalgam, sulfide minerals and zircon. The minimum recovery of gold particles is 95\% using the mechanical Wilfley table panning technique (English et al., 1987).

Each of the obtained magnetic fractions is quartered to obtain representative samples. Each sample is individually weighed and spread on a glass plate for binocular microscopic examination. Furthermore, about 500 to 1000 grains are counted at different random fields to calculate the frequency of the constituent minerals. The weight percent of each mineral in every subfraction is calculat- 
ed according to Strakhov et al. (1957).

Hand picking under binocular microscope obtain the pure mineral separates. The heavy fractions are studied microscopically in order to distinguish the opaque and non-opaque minerals. The spot micro semi-quantitative chemical analysis of the studied heavy minerals are achieved using the environmental scanning electron microscope (ESEM) attached with energydispersive X-ray unit (EDX) model Philips XL 30. The acquired backscattered electron images (BSE) with resolution of 3.5 $\mathrm{nm}$ at $25-30 \mathrm{kV}$ characterize the micromorphology of the stream sediments grains under investigation. This technique becomes more precise through the standard (ZAF) matrix correction software.

\section{RESULTS AND DISCUSSIONS}

\section{Grain Size Analysis}

Each sample was discriminated into fractions using an automatic shaker having set of standard sieves followed by sluicing and panning. Statistical grain size parameters are calculated according to the formulae given by Folk and Ward (1957). Grain size is distinctly variable, being represented by fine pebbles, granules and different sand sizes ranging from fine to very coarse sand size (Table 1).

Mean size $\left(\mathrm{M}_{\mathrm{z}}\right)$ is distinctly variable, being represented by fine pebbles, granules and different sand sizes from very coarse to fine . It is clear that the very coarse sand is the most frequent fraction (33\%), whereas the least frequent fraction is represented by fine pebbles $(6 \%)$. Medium sand size is only reported for two samples (samples No. 8 and 18). Fine sand size is also reported for two samples (samples No. 12 and 16). The inclusive graphic standard deviation values of the studied stream sediments range from poorly sorted to very poorly sorted. Statistically, $72 \%$ of the studied samples are poorly sorted while $28 \%$ of these samples are very poorly sorted (Fig. 3).
Table 1: Range and average frequency distribution of mechanical parameters of Wadi Hangaliya stream sediments (No. Sp. $=18)$

Graphic mean size $\left(\mathrm{M}_{\mathrm{z}}\right)$

\begin{tabular}{|c|c|c|c|c|c|c|}
\hline \multirow{2}{*}{\multicolumn{2}{|c|}{$\begin{array}{l}\text { Fine pebble } \\
-6.0 \cdot-2.0 \phi\end{array}$}} & & V.C.S. & C.S. & M. S. & \\
\hline & & $-2.0 \cdots 1.0 \phi$ & $-1.0-0.0 \phi$ & $0.0-1.0 \phi$ & $1.0-2.0 \phi$ & $2.0-3.0 \phi$ \\
\hline No. & $\%$ & No. $\%$ & No. & No. & No. & No. \\
\hline 1 & 5.56 & 211.11 & 633.33 & 527.78 & 211.11 & 211.11 \\
\hline
\end{tabular}

Inclusive graphic standard deviation $\left(\sigma_{\mathrm{i}}\right)$

\begin{tabular}{|c|c|}
\hline $\begin{array}{l}\text { V.P.S. } \\
2.0-4.0 \phi\end{array}$ & $\begin{array}{r}\text { P.S. } \\
2.0-1.0 \phi\end{array}$ \\
\hline $\begin{array}{cr}\text { No. } & \% \\
5 & 27.78 \\
\end{array}$ & $\begin{array}{rr}\text { No. } & \% \\
13 & 72.22\end{array}$ \\
\hline
\end{tabular}

Inclusive graphic skewness $\left(\mathrm{Sk}_{\mathrm{i}}\right)$

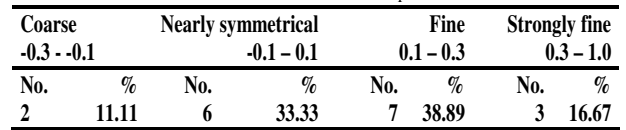

Graphic kurtosis $\left(\mathrm{K}_{\mathrm{G}}\right)$

\begin{tabular}{|c|c|c|c|c|c|c|c|}
\hline \multicolumn{2}{|c|}{$\begin{array}{l}\text { Platykurtic } \\
0.67-0.9\end{array}$} & \multicolumn{2}{|c|}{$\begin{array}{c}\text { Mesokurtic } \\
0.90-1.11\end{array}$} & \multicolumn{2}{|c|}{$\begin{array}{r}\text { Leptokurtic } \\
1.11-1.3\end{array}$} & \multicolumn{2}{|c|}{$\begin{array}{r}\text { Very } \\
\text { leptokurtic } \\
>1.3 \\
\end{array}$} \\
\hline No. & $\%$ & No. & $\%$ & No. & $\%$ & No. & $\%$ \\
\hline 3 & 16.67 & 6 & 33.33 & 5 & 27.78 & 2 & 11.1 \\
\hline
\end{tabular}

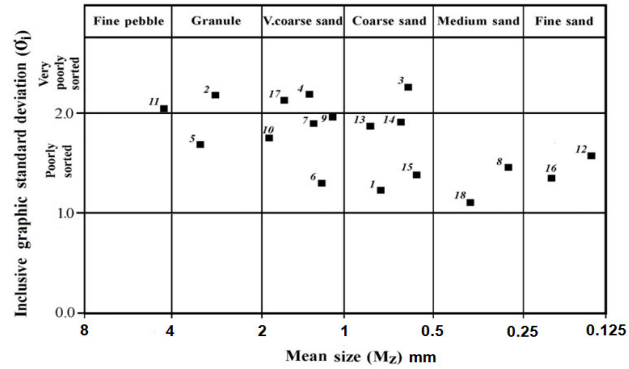

Fig. 3: Mean size $\left(\mathrm{M}_{\mathrm{z}}\right)$ versus inclusive standard deviation $\left(\sigma_{i}\right)$ diagram showing the poor sorting of Wadi Hangaliya stream sediments

It is shown that about $11 \%$ of the studied samples are coarse skewed. 33\% and 39\% of samples show nearly symmetrical and fine skewed, respectively and $17 \%$ show very finely skewed. Concerning kurtosis, $61 \%$ of the studied samples are represented by the mesokurtic and leptokurtic classes. Platykurtic and very leptokurtic classes are less frequent (17 and $11 \%$ respectively). 


\section{Heavy Liquid and Isodynamic Separation}

\section{Light fraction}

The light fractions of western extremity of Wadi Hangaliya (in comparison with its eastern extremity) show major constituents of light minerals of quartz and potash feldspars. Lesser amounts of orthoclase, micas (muscovite and biotite) are also recorded.

\section{Heavy Fraction}

Tables $(2 \& 3)$ and Figs. (4 \& 5) summarize the recorded total heavy mineral percentages in the studied samples. Figure (4) illustrates a comparison between heavy mineral percent of both studied sand fractions. The relationship shows heavy mineral content in both sand size fractions (fine and very fine) reaching up its maximum order in the area between stations 12 and 13 .

The relationship shows a zigzag line with mild increase toward downstream in case of the very fine sand fraction. It shows more progressive increase downstream in case of fine sand fraction.

Table (2) shows that sediments of Wadi Hangaliya are relatively enriched in heavy

Table 2: Distribution of the total heavy fraction (\%) of Wadi Hangaliya stream sediments

\begin{tabular}{lll}
\hline & & Size class \\
S. & Fine Sand & \\
\hline 1 & 2.71 & Very \\
2 & 3.20 & 1.13 \\
3 & 2.56 & 1.81 \\
4 & 4.65 & 1.05 \\
5 & 2.73 & 0.97 \\
6 & 5.16 & 2.36 \\
7 & 4.12 & 1.45 \\
8 & 5.68 & 2.77 \\
9 & 4.29 & 3.12 \\
10 & 7.37 & 2.31 \\
11 & 6.32 & 2.55 \\
12 & 8.73 & 2.89 \\
13 & 8.77 & 3.57 \\
14 & 7.93 & 3.02 \\
15 & 6.37 & 2.73 \\
16 & 8.36 & 2.99 \\
17 & 7.22 & 3.32 \\
18 & 8.53 & 3.06 \\
Ave & 5.82 & 2.33 \\
\hline
\end{tabular}

Table 3: Relative percentage of heavy minerals content of Wadi Hangaliya stream sediments

\begin{tabular}{|c|c|c|c|c|c|c|}
\hline \multirow{3}{*}{ Mineral } & \multicolumn{6}{|c|}{ Size class } \\
\hline & \multicolumn{3}{|c|}{ Fine sand fraction } & \multicolumn{3}{|c|}{ Very fine sand fraction } \\
\hline & Min. & Max. & Av. & Min. & Max. & Av \\
\hline Opaques ${ }^{3}$ & 8.9 & 21.8 & 13.3 & 4.8 & 22.4 & 14.6 \\
\hline $\begin{array}{l}\text { Amphiboles } \\
\text { and pyroxenes }\end{array}$ & 7.4 & 22.4 & 14.1 & 3.6 & 20.0 & 11.2 \\
\hline Epidote & 0.7 & 12.7 & 3.4 & 0.3 & 4.2 & 2.0 \\
\hline Apatite & 0.6 & 2.3 & 1.2 & 0.2 & 1.7 & 0.7 \\
\hline Titanite & 0.9 & 5.2 & 1.3 & 0.0 & 1.1 & 0.8 \\
\hline Zircon & 0.3 & 15.7 & 5.3 & 0.2 & 6.7 & 3.8 \\
\hline Rutile & 0.0 & 7.0 & 2.1 & 0.0 & 2.9 & 1.1 \\
\hline Staurolite & 0.1 & 6.1 & 2.9 & 0.0 & 4.1 & 1.7 \\
\hline Sillimanite & 0.2 & 11.3 & 3.6 & 0.1 & 3.4 & 2.8 \\
\hline Monazite & 0.0 & 1.5 & 0.4 & 0.0 & 0.8 & 0.2 \\
\hline Garnet & 0.0 & 3.8 & 1.1 & 0.0 & 2.1 & 0.4 \\
\hline Barite & 0.2 & 14.8 & 2.4 & 0.0 & 8.9 & 0.8 \\
\hline Tourmaline & 0.2 & 4.9 & 0.9 & 0.1 & 2.4 & 0.6 \\
\hline Total & 19.5 & 129.5 & 52 & 9.3 & 80.7 & 40.7 \\
\hline
\end{tabular}

*Include ilmenite, hematite, leucoxene, pyrite and magnetite

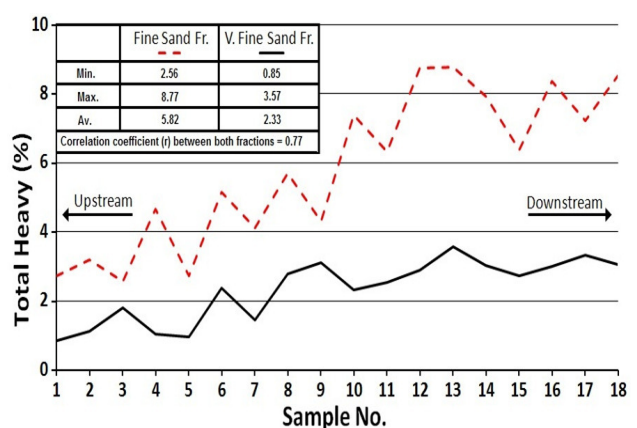

Fig. 4: Comparison between total heavy (\%) in both studied sand size fractions of Wadi Hangaliya stream sediments

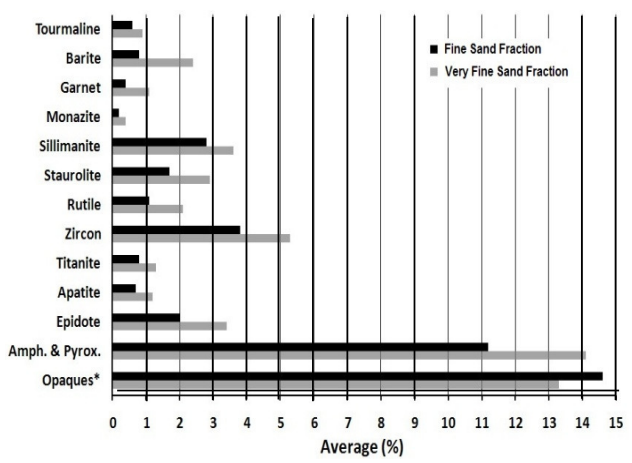

Fig. 5: Average percentages of heavy minerals content of Wadi Hangaliya stream sediments. ${ }^{*}=$ (ilmenite, hematite, leucoxene and magnetite) 
minerals. The total heavy fraction (\%) of the fine sand fraction ranges between 2.56 and $8.77 \%$, whereas in the very fine sand sized ranges varies between 0.85 and $3.57 \%$. Averages of abundance of the heavy minerals in both fractions are $5.82 \%$ and $2.33 \%$, respectively.

\section{Mineralogy}

The mineralogical study is achieved using a normal optical microscope as well as a scanning electron microscope. Table (3) shows the percentage of the heavy minerals investigated in the studied stream sediments. From Table (3) and Fig. (4), it is clear that the fine sand fraction is rich by heavy mineral than the very fine sand fraction. The heavy mineral assemblage of Wadi Hangaliya shows a variation; sediments contain an immature (or unstable) heavy-mineral assemblage dominated by hornblende and epidotes, whereas the more mature (or stable) suites are dominated by zircon, ilmenite, staurolite, sillimanite, tourmaline, rutile and other minerals more resistant to weathering (Table 4).

It is observed that Wadi Hangaliya stream sediment samples are characterized by average green silicates of (14.1 and $11.2 \%$ for the fine and very fine sand fractions, respectively), opaques which include the hematite, leucoxene and magnetite (13.3 and 14.6\%).

On the other hand, barite frequency is 2.4 and $0.8 \%$ in the fine and very fine sand frac-

Table 4 : EDX micro chemical analysis of Fe-Ti oxides

\begin{tabular}{|c|c|c|c|c|c|}
\hline \multirow[t]{3}{*}{ Oxides $\%$} & \multirow{2}{*}{\multicolumn{4}{|c|}{ Ilmenite*: }} & \multirow{2}{*}{$\begin{array}{l}\text { Analysis No. } \\
\text { omagnetite }\end{array}$} \\
\hline & & & & & \\
\hline & 1 & 2 & 3 & 4 & \\
\hline$\overline{\mathrm{TiO}_{2}}$ & 37.96 & 40.21 & 20.30 & 23.22 & $\overline{8.12}$ \\
\hline $\mathrm{MnO}$ & 1.61 & 1.08 & 1.23 & 1.41 & 0.52 \\
\hline $\mathrm{Fe}_{2} \mathrm{O}_{3}$ & 37.15 & 38.98 & 44.80 & 41.59 & 81.03 \\
\hline $\mathrm{CaO}$ & 4.37 & 4.09 & 6.37 & 6.76 & 1.53 \\
\hline $\mathrm{SiO}_{2}$ & 18.91 & 16.72 & 28.53 & 28.43 & 8.8 \\
\hline Total & 100 & 100 & 100 & $\mathbf{1 0 0}$ & 98.02 \\
\hline
\end{tabular}

* Analyses (1 and 2) of two different spots of the lighting area in the grains showing on Fig. (6b and c) respectively; analyses 3 and 4 of dark areas of the same grains (Fig. $6 \mathrm{~b}$ and c) respectively.

** Magnetite hosting ilmenite (the grain shown on Fig. (6d). Low total of the analysis is attributed the presence of chromium oxides trace of $1.98 \%$ tions respectively, titanite 1.3 and $0.8 \%$, sillimanite 3.6 and $2.8 \%$, staurolite 2.9 and $1.7 \%$, garnet 1.1 and $0.4 \%$, apatite 1.2 and $0.7 \%$ and monazite 0.4 and $0.2 \%$. The recorded frequencies of ZTR minerals show zircon from 5.3 to $3.8 \%$, rutile from 2.1 to $1.1 \%$, tourmaline from 0.9 to $0.6 \%$ in fine and very fine sand fractions, respectively.

\section{Opaque minerals}

The studied stream sediments show high content of opaques (Table 3). The opaques content ranges from 9 to $22 \%$ with an average of about $13 \%$ in the fine sand fraction, while in the very fine sand fraction opaques range between 5 to $22 \%$ with an average of about $15 \%$. The opaques are represented by ilmenite, magnetite, hematite and leucoxene minerals.

\section{Pyrite $\left(\mathrm{FeS}_{2}\right)$}

Pyrite shows well developed octahedron crystals with pale-brass yellow colour and metallic luster. Pyrite is usually disseminated in the altered rocks of the Gabal Nugrus shear zone (El Feky, 2000, El Feky et al., 2004, Raslan and Ali, 2010). Generally, pyrite crystals of the studied stream sediments were oxidized to hematite and goethite (Fig. 6 ). The average pyrite content of the opaques was 3.82 and $3.14 \%$ in fine and very fine sand size fractions, respectively.

\section{Ilmenite ( $\left.\mathrm{FeTiO}_{3}\right)$}

Ilmenite represents the most abundance opaque mineral in Wadi Hangaliya stream sediments. Ilmenite is concentrated in the fine sand sized fraction and occurs as sub-angular to angular. The average content of ilmenite is about $16 \%$ and $14.8 \%$ of the opaque minerals in fine and very fine sand sized fractions, respectively. Table (4) gives spot analyses of fresh ilmenite (analyses No. 1 and 2) and may alter ones (silica increases), (analyses No. 3 and 4).

\section{Magnetite ( $\left.\mathrm{Fe}_{3} \mathrm{O}_{4}\right)$}

Magnetite is less stable mineral and can be altered to hematite. It occurs as angular 


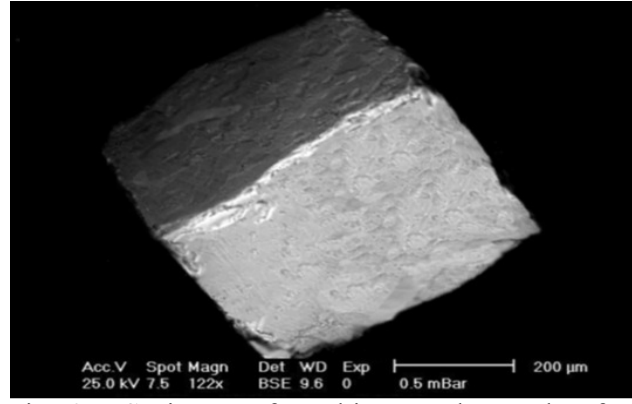

Fig. 6: BSE image of goethite pseudomorphs afte pyrite

to sub-angular, medium to fine grains. Magnetite ranges from 4.85 to $18.25 \%$ with an average content $6.5 \%$ in the fine sand size fraction. In the very fine sand size fraction it ranges from 3.91 to $14.58 \%$ with an average $4.4 \%$ of the opaques. Most of the recorded magnetite is characterized by relatively high contents of $\mathrm{TiO}_{2}$ and $\mathrm{Cr}_{2} \mathrm{O}$ indicating of mafic origin. Whereas, the low content of $\mathrm{TiO}_{2}$ and $\mathrm{Cr}_{2} \mathrm{O}_{3}$ suggest that the origin source rock may be granite (Lyakhovich and Lyakhovich, 1983).

The ESEM investigations prove the presence of ilmenite-magnetite composite particles (Fig. 7). The relative chemical composition of some magnetite grains indicates a distinct titanomagnetite variety with $\mathrm{TiO}_{2}$ amounting 8.12 wt. \% (Fig. 8 and Table 4).

\section{Precious metals}

Silver (Ag) occurs as inclusions within the chalcopyrite (Raslan and Ali, 2010). These inclusions are occurring as very light grey anhedral to subhedral crystals and ranging in size from 5 to $10 \mu \mathrm{m}$ (Fig. 9). Two spot had been done (Table 5). EDX analyses indicate that silver content ranges between 98 and 99 $\%$ besides traces of $\mathrm{Au}(0.61-1.21 \%)$ and $\mathrm{Cu}(0.16-0.27 \%)$.

Gold $(\boldsymbol{A} \boldsymbol{u})$ content in the stream sediments of Wadi Hangaliya is determined for 18 representative samples $(0.5 \mathrm{~kg}$ for each one). The primarily determination of gold content
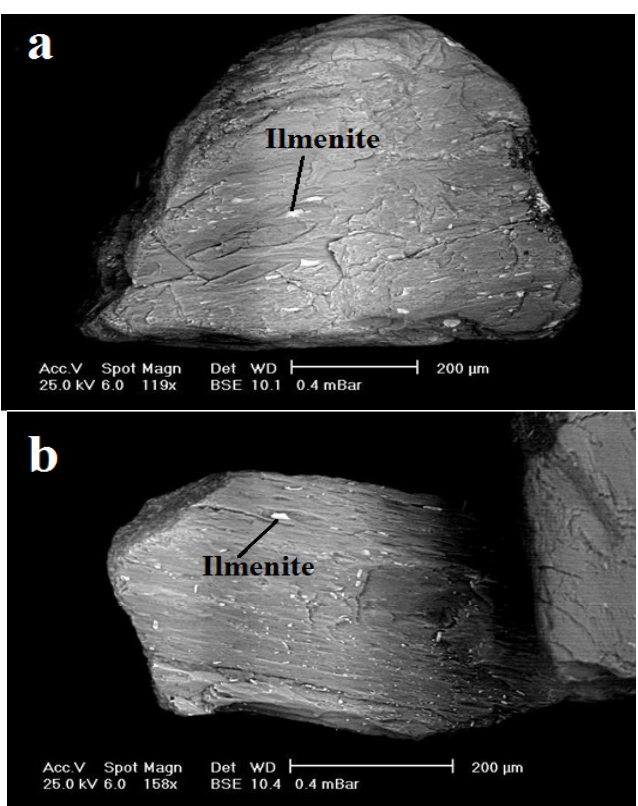

Fig. 7: BSE images of a \& b magnetite (dark) hosting ilmenite (white composite particles)

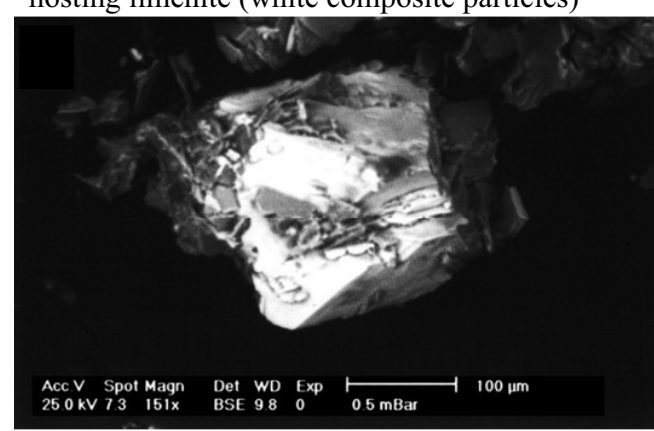

Fig. 8: BSE image of titano-magnetite (light) hosted in alkali feldspars

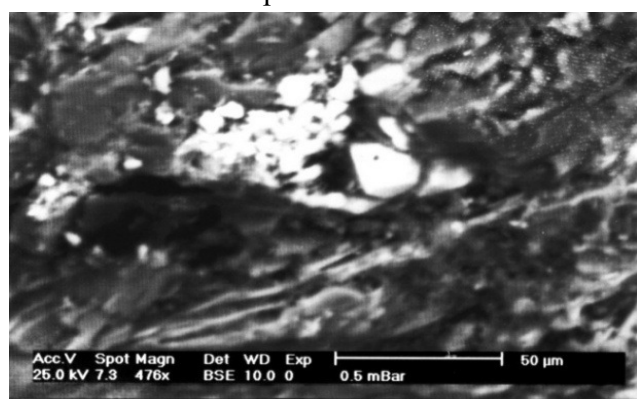

Fig. 9: BSE image of native silver aggregates (bright colour) occurs as inclusions within chalcopyrite (dark) 
using the Wilfley wet shaking table with gold panning was carried out on sieved samples $(<0.250 \mathrm{~mm})$. Recovered gold grains cover the grain size ranging from $<0.250 \mathrm{~mm}$ to $\sim 0.40 \mathrm{~mm}$ (fine sand - silt). Several particles of the detected gold are subjected to the microscopic study as well as (ESEM) investigations (Fig. 10 and Table 6).

The occurrence of gold in the studied stream sediments may be present as free par-

Table 5: EDX micro chemical analysis of silver (light crystals, Fig. 7

\begin{tabular}{lrr}
\hline Element & & Analysis No. \\
$\%$ & 1 & 2 \\
\hline Ag & 98.63 & 99.12 \\
Au & 1.21 & 0.61 \\
Cu & 0.16 & 0.27 \\
Total & 100 & 100 \\
\hline
\end{tabular}

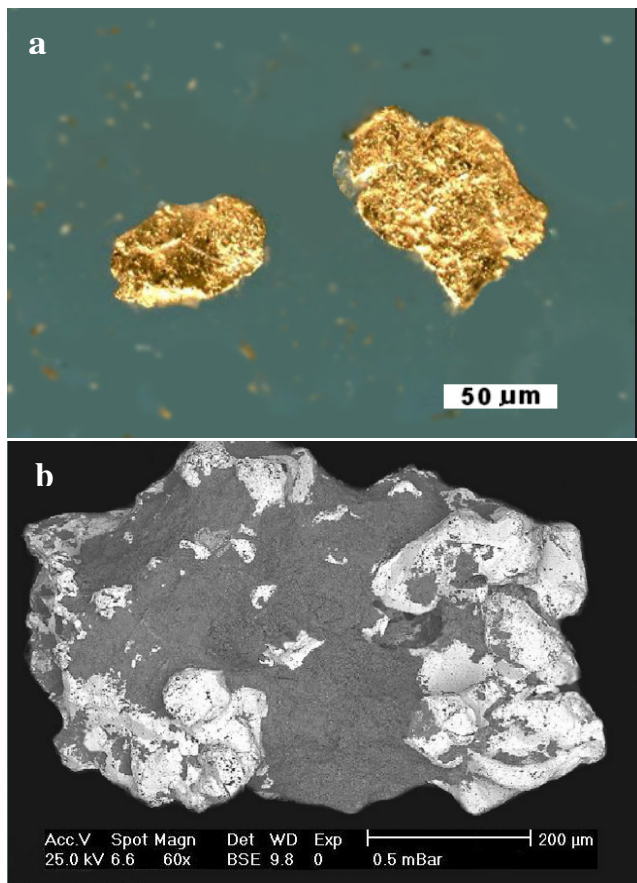

Fig. 10: Photomicrograph showing selected gold aggregates from the fine sand size fraction (a) and BSE image of gold showing to the left (b)
Table 6: EDX micro chemical analysis of gold

\begin{tabular}{lrrrr}
\hline $\begin{array}{l}\text { Element } \\
\%\end{array}$ & 1 & $2 *$ & 3 & 4 \\
\hline $\mathrm{Au}$ & 75.3 & 98.2 & 82.1 & 100 \\
$\mathrm{Ag}$ & 22.6 & - & 26.6 & - \\
$\mathrm{Fe}$ & 2.1 & 0.6 & 1.3 & - \\
$\mathrm{Cu}$ & - & 1.2 & - & - \\
Total & 100 & 100 & 100 & 100 \\
\hline
\end{tabular}

ticle or inclusion within sulphide. Raslan and Ali, 2010; El Feky et al., 2004 recorded invisible gold inclusion within sulphides (chalcopyrite and pyrite) in the auriferous shear zone of Gabal Nugrus which may be the main source of gold in the stream sediments of western extremity of Wadi Hangliya.

There is a relation between gold occurrence and the interaction of the granites with the ultramafics and metagabbro-diorite rocks association (Khalil and Helba, 1998). According to Surour et al. (2001) the source of gold is multiple and being leached from ophiolitic serpentinites, arc-metavolcanics and sulphide-bearing dolerite dykes.

Table (7) shows that about $72 \%$ of the studied stream sediments contain gold; up to $4.141 \mathrm{~g} /$ ton $\mathrm{Au}$ with average of $1.135 \mathrm{~g} / \mathrm{t}$ $\mathrm{Au}$. The gold content may be increased if we considered non librated gold grains which

Table 7: Preliminary estimation of gold content $(\mathrm{g} / \mathrm{t})$ in Wadi Hangaliya stream sediments $(<0.250$ mm fraction)

\begin{tabular}{|c|c|c|c|c|c|}
\hline $\begin{array}{l}\text { S. } \\
\text { No. }\end{array}$ & $\begin{array}{r}\text { Au content } \\
(\mathrm{g} / \mathrm{t})\end{array}$ & $\begin{array}{r}\text { S. } \\
\text { No. }\end{array}$ & $\begin{array}{r}\text { Au content } \\
(\mathrm{g} / \mathrm{t})\end{array}$ & S. No. & $\begin{array}{l}\text { Au content } \\
\qquad(\mathrm{g} / \mathrm{t})\end{array}$ \\
\hline 1 & 1.484 & 7 & 4.141 & 13 & 0.746 \\
\hline 2 & 1.076 & 8 & 1.620 & 14 & 0.879 \\
\hline 3 & 2.984 & 9 & - & 15 & 1.194 \\
\hline 4 & 2.853 & 10 & - & 16 & 0.732 \\
\hline 5 & 1.515 & 11 & - & 17 & . \\
\hline 6 & 0.92 & 12 & $\therefore$ & 18 & 0.29 \\
\hline \multicolumn{6}{|c|}{ Average $=1.135 \mathrm{~g} / \mathrm{ton} \mathrm{Au}$} \\
\hline
\end{tabular}


still hosted in the size class larger than 0.250 $\mathrm{mm}$.

The maximum gold content of Wadi Hangaliya stream sediments occurs in the very fine sand size fraction $(73 \%)$. The coarser gold grains in the fine sand size fraction is also recorded with $16 \%$, while gold grains less than coarse silt size $(<0.063 \mathrm{~mm})$ represent $11 \%$. The gold content in the stream sediments can be related to the original size of gold in the host rocks and the distance of transportation. Surour et al. (2003) in their work on a similar arid area at Wadi Dahab (south Sinai) concluded that the relief and mechanical weathering are the main controlling factors in the development of gold placers. Mining and extraction of gold from loose sediments containing free gold is inexpensive.

The area of Wadi Hangaliya was occupying an ancient gold mining activity and there were remnant of ancient houses in the area which the wadi cuts Gabal Nugrus (western part of the wadi). A logic thinking that lead to found the gold in the stream sediments in this portion of the wadi, but it was a surprise that gold occurrences also recovered from the south eastern and eastern extremities of the wadi. This agrees with the hypothesis of Surour et al. (2001). It is a fact that these portions of the wadi cutting throw the metavolcanics and ophiolitic serpentinites rocks (Fig. 1a). According to Surour et al. (2001) the later rock unit may be the source of gold occurrences recorded in the samples (1 to 6) in the present work.

\section{Non-opaque minerals}

\section{Titanite (CaTiSO $)$}

Titanite occurs as equal grains, reddish to orange (Fig. 11). The recorded titanite in the studied samples has an average content of 1.3 to $0.8 \%$ in the fine and very fine sand size fractions, respectively (Table 8). EXD micro semi-quantitative chemical analyses of titanite show remarkable depletion in $\mathrm{MnO}$ content indicating that the $\mathrm{Mn}^{2+}$ ions are li-

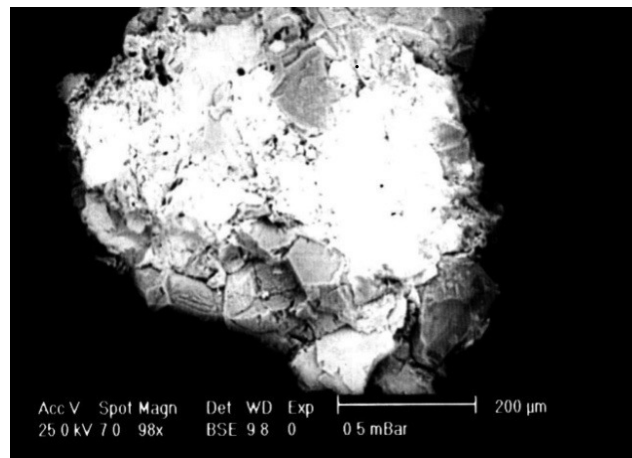

Fig. 11: BSE image showing titanite (light) replacing ilmenite (dark)

Table 8: EDX micro chemical analysis of titanite

\begin{tabular}{lr}
\hline Oxide & Titanite* \\
\hline $\mathrm{TiO}_{2}$ & 34.18 \\
$\mathrm{MnO}$ & - \\
$\mathrm{CaO}$ & 31.12 \\
$\mathrm{Fe}_{2} \mathrm{O}_{3}$ & $\mathbf{1 . 2 9}$ \\
$\mathrm{SiO}_{2}$ & $\mathbf{3 2 . 0 4}$ \\
Total & $\mathbf{9 8 . 6 3}$ \\
\hline - Not detected. & \\
* Titanite replacing ilmenite (the aggregate shown on Fig. \\
9). Low total due to presence of traces of $\mathrm{V}$ and Cr oxides.
\end{tabular}

brated upon alteration of ilmenite to titanite (Moufti, 2009).

\section{Monazite (Ce, $\mathrm{La}, \mathrm{Pr}, \mathrm{Nd}, \mathrm{Th}, \mathrm{Y}) \mathrm{PO}_{4}$}

The radioactive minerals in Wadi Hangaliya stream sediments are only represented by two minerals; thorite and monazite, in addition to metamict zircon variety as proved by the EDX micro- semi-quantitative chemical analysis. Monazite average contents are 0.4 and $0.2 \%$ in the fine and very fine sand size fractions respectively. Monazite grains are colourless to yellow and occur as subhedral crystals (Fig. 12). Monazite may be derived from granites and pegmatites being common in Gabal Nugrus (El Feky, 2000).

The EDX analysis of four different grains of monazite (Table 9) shows remarkably high contents of rare earth elements (REE) such as $\mathrm{La}, \mathrm{Ce}, \mathrm{Nd}, \mathrm{Pr}, \mathrm{Eu}$ and $\mathrm{Gd}$, also Th con- 


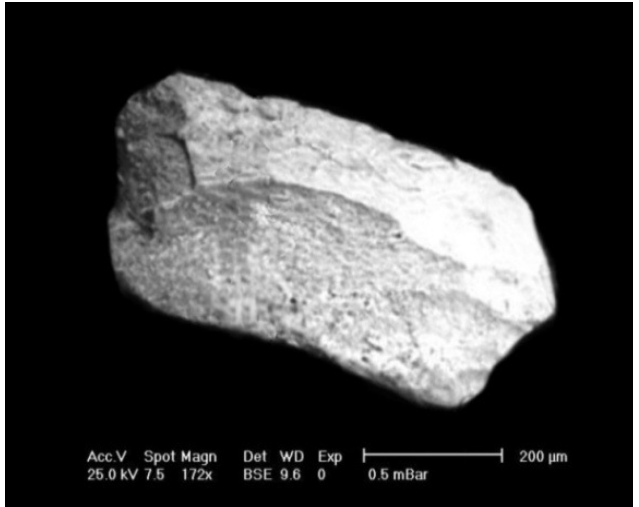

Fig.12: BSE image of monazite

Table 9: EDX micro chemical analysis of monazite

\begin{tabular}{lrr}
\hline Element & & Analysis No. \\
\% & 1 & $\mathbf{1}$ \\
\hline Fe & 11.49 & 16.20 \\
P & 12.89 & 19.87 \\
Th & 3.61 & 6.59 \\
Ca & 1.94 & 1.28 \\
Ta & 1.33 & 2.12 \\
Ce & 28.47 & 22.17 \\
La & 23.44 & 14.56 \\
Nd & 8.58 & 12.01 \\
Pr & 3.66 & 3.22 \\
Gd & 0.15 & 0.13 \\
Eu & 0.61 & 0.55 \\
Total & 96.17 & 98.70 \\
\hline
\end{tabular}

tent from 3.61 to $6.59 \mathrm{Wt}$. \%. Some traces of both $\mathrm{CaO}$ (1.94 Wt. \%) and $\mathrm{Ta}_{2} \mathrm{O}_{5}(1.33 \mathrm{Wt}$. $\%$ ) have been recorded where the prior can be attributed to the presence of fine apatite inclusions or denotes $\mathrm{Ca}$ in the host silicate structure (Farid, 2005); (Table 9, analyses No. 2).

\section{Thorite (ThSiO)}

It recorded as prismatic subhedral crystals. The chemical analyses of thorite (Fig. 13 and Table 10) shows variable amounts of uranium started from U-free thorite (analysis No. 1) to uranothorite (analysis No. 2) containing up to

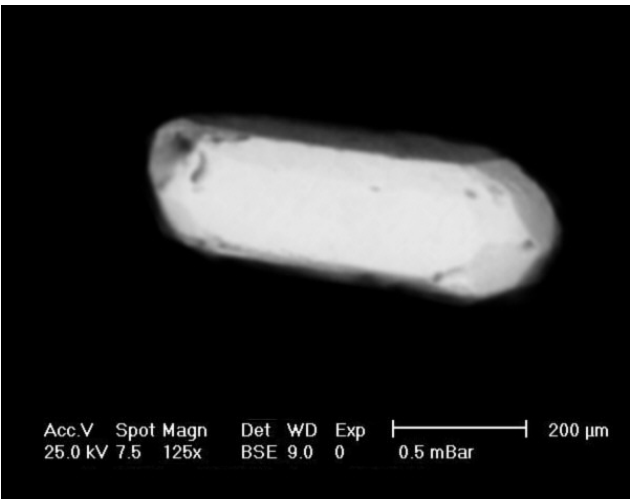

Fig. 13: BSE image of thorite

Table 10: EDX micro chemical analysis of thorite

\begin{tabular}{|c|c|c|}
\hline \multirow{2}{*}{$\begin{array}{l}\text { Element } \\
\%\end{array}$} & \multicolumn{2}{|c|}{ Analysis No. } \\
\hline & 1 & 2 \\
\hline $\mathbf{S i}$ & 10.21 & 5.55 \\
\hline Al & - & 1.53 \\
\hline $\mathbf{F e}$ & - & 1.40 \\
\hline Th & 69.51 & 43.30 \\
\hline $\mathbf{U}$ & 0.01 & 9.15 \\
\hline $\mathbf{P}$ & 4.38 & 5.42 \\
\hline $\mathbf{S}$ & - & 2.63 \\
\hline $\mathbf{Z r}$ & 4.12 & 3.89 \\
\hline Ce & 0.93 & 6.56 \\
\hline $\mathbf{Y}$ & 5.67 & 5.10 \\
\hline $\mathbf{C a}$ & 2.43 & 3.69 \\
\hline La & 0.56 & 3.44 \\
\hline Nd & 0.82 & 2.40 \\
\hline As & - & 1.53 \\
\hline Pr & 0.22 & 1.50 \\
\hline $\mathbf{Y b}$ & - & 1.21 \\
\hline Sm & 0.14 & 0.59 \\
\hline Gd & 0.5 & 0.53 \\
\hline Eu & 0.5 & 0.36 \\
\hline Hf & - & 0.22 \\
\hline Total & 100 & 100 \\
\hline
\end{tabular}

9.15 Wt. \% U. The U-free thorite grains are LREE-bearing in comparison of uranothorite which was LREE- and HREE.

\section{Zircon ( $\mathrm{ZrSiO}_{4}$ )}

Zircon represents about $5.3 \%$ of the aver- 
age content of fine sand size heavy fraction and $3.8 \%$ of the average content of very fine sand size of heavy minerals in Wadi Hangaliya stream sediments (Table 3 ).

Zircon occurs as short or long prismatic crystals with or without bipyrmidal terminations. Basal tetragonal grains are much less frequent. Most of the recorded zircons are subhedral idiomorphic bipyramidal broken crystals that may be derived from nearby basement rocks. Colourless, pale pink and metamict zircon are also recorded; the later confirmed by EDX micro semi-quantitative chemical analysis (Table 11). The zircon grains are most stable heavy mineral and sometimes etched, corroded or partly dissoluted or affected by metamict disintegration. In some cases, a fringe of zirconium rich silicates considered as resulting of hydrothermal growth in the parent rocks surrounds a previous prismatic zircon (Fig. 14 and Table 11 analyses No. 3 and 4). The EDX analyses of zircon grains hosted in feldspars (Fig. 14, Table 11 analyses No. 1 and 2) are relatively contain $\mathrm{Zr}$ up to $74.3 \mathrm{Wt}$. \% and $\mathrm{Si}$ up to $18.9 \mathrm{Wt} . \%$, and subordinate amount Hf and Yb. Most of zircon grains are HREE-bearing and sometimes bear up to $3.3 \mathrm{Wt}$. \% Hf (Table 11). Also, $\mathrm{U}$ and Th content recorded in zircon grains reach up to 0.8 and 1.4 respectively.

Table 11: EDX micro chemical analysis of zircon

\begin{tabular}{|c|c|c|c|c|}
\hline \multirow{2}{*}{$\begin{array}{l}\text { Element } \\
\% \\
\end{array}$} & & & \multicolumn{2}{|c|}{ Analysis No. } \\
\hline & 1 & 2 & 3 & 4 \\
\hline $\mathrm{Si}$ & 18.92 & 61.30 & 19.21 & 56.03 \\
\hline $\mathrm{Zr}$ & 74.31 & 33.22 & 51.06 & 42.13 \\
\hline Hf & 3.25 & 3.23 & - & 1.62 \\
\hline $\mathbf{U}$ & 0.82 & 0.83 & 0.16 & 0.12 \\
\hline Th & 1.40 & 1.42 & 0.66 & 0.10 \\
\hline HREE & $1.3^{*}$ & - & $28.91 * *$ & - \\
\hline Total & 100 & 100 & 100 & 100 \\
\hline
\end{tabular}

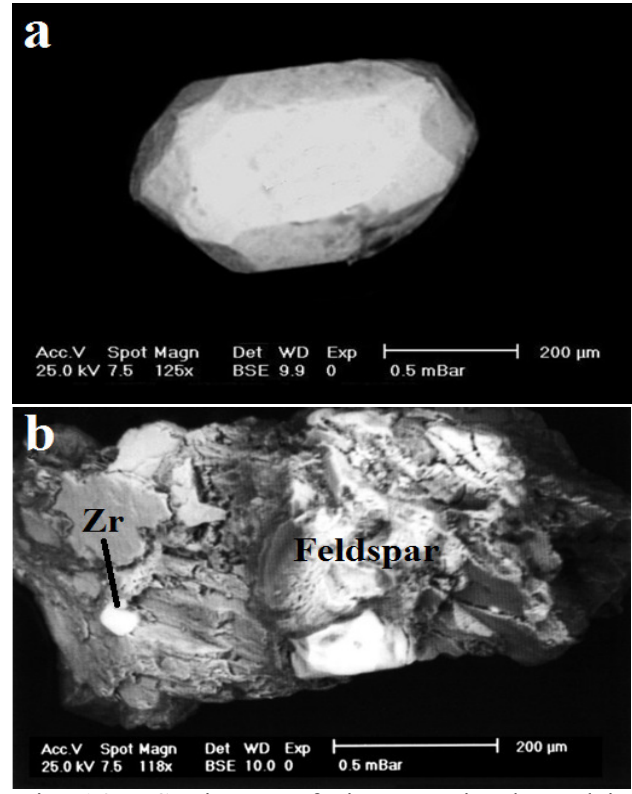

Fig. 14: BSE image of zircon grains hosted in silicate (a) (see analyses 3 and 4) and feldspar (b) (see analyses 1 and 2)

\section{Garnet ( Fe,Mg,Mn, Cr, Ti, CaAlSiO )}

Garnet group represents about $1.1 \%$ of the average content of heavy fraction and $0.4 \%$ of the average content of heavy minerals in Wadi Hangaliya stream sediments (Table 3). Almandine ( $\left.\mathrm{Fe}^{2+} \mathrm{AlSiO}\right)$ garnets occur as violet-red to brown or black. Andradite $\left(\mathrm{Fe}^{3+} \mathrm{CaSiO}_{4}\right)$ garnets (Fig. 15) also recorded in the studied sediments with less abundance in comparison to almandine garnets. The different types of occurred garnets are confirmed by ESEM. Table (12) summarized their micro semi-quantitative chemical analyses of almandine and andradite garnets.

\section{Rutile ( $\mathrm{TiO}_{2}$ )}

Rutile is an important economic heavy mineral. It occurs as elongated, needle like and prismatic grains (Fig. 16) with a foxy red, reddish brown to opaque colour. Rutile represents about $2.1 \%$ of the average content of 


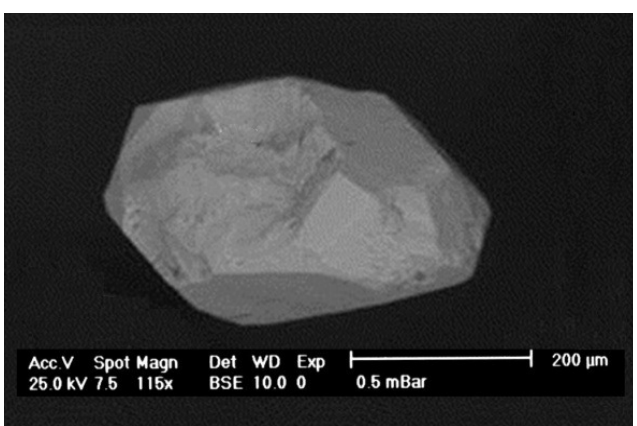

Fig. 15: BSE image of andradite garnet

Table 12: EDX micro chemical analysis of garnet

\begin{tabular}{l|rr}
\hline Element & Almandine & Analysis No. \\
$\%$ & Andradite \\
\hline Si & 33.08 & 19.65 \\
Fe & 41.37 & 63.12 \\
Al & 24.62 & 0.11 \\
Ca & 0.46 & 14.57 \\
Total & 99.53 & 97.45 \\
\hline \multicolumn{2}{l}{} \\
Low total due to presence of trace elements
\end{tabular}

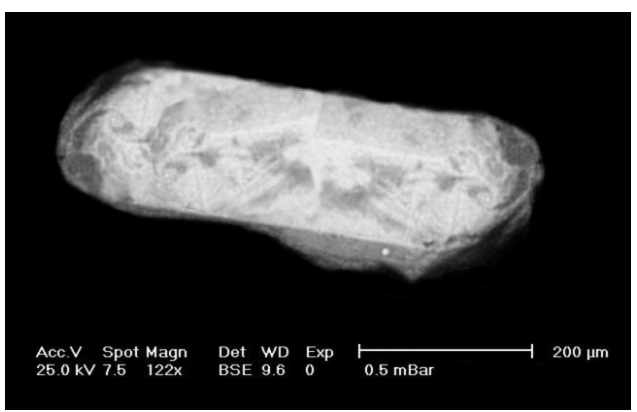

Fig. 16: BSE image of rutile

heavy fraction and 1.1 of the average content of heavy minerals in Wadi Hangaliya stream sediments (Table 3).

\section{Green silicates}

The heavy fractions of the studied samples show enrichment of green silicates which mostly include amphiboles and pyroxenes. There is no economic importance to these silicates. It found in the studied samples with an average content of 14.1 and $11.2 \%$ in the fine and very fine sand size fractions, respectively (Table 3). Hornblende dominates the amphibole minerals; represented by brown and green varieties. The brown variety; Tirich, subhedral and prismatic was probably derived from the non-ophiolitic or younger gabbros (Basyoni and Surour, 2006). On the other hand, green hornblende is probably derived from the calc-alkaline granitoids or metamorphic rocks. The pyroxenes are represented by augite.

\section{Epidotes $\mathrm{Ca}_{2} \mathrm{Al}_{2}\left(\mathrm{Fe}^{3+}, \mathrm{Al}\right)\left(\mathrm{SiO}_{4}\right)\left(\mathrm{Si}_{2} \mathrm{O}_{7}\right) \mathrm{O}(\mathrm{OH})$}

Epidote group are represented by average contents of 3.4 and $2.0 \%$ of the fine and very fine sand size fractions in the studied samples, respectively (Table 3 ). Epidote minerals are represented by zoisite and pistachite. It is difficult to distinguish the source of epidotes because it could be derived from both acidic and mafic rocks in the hinterlands.

\section{Apatite $\mathrm{Ca}_{10}\left(\mathrm{PO}_{4}\right)_{6}(\mathrm{OH}, \mathrm{F}, \mathrm{Cl})_{2}$}

It is found in the studied samples with an average content of 1.2 and $0.7 \%$ in the fine and very fine sand size fractions, respectively (Table 3). Apatite crystals often clear, but some turbid crystals are rare. It is commonly euhedral and the outlines are either prismatic or basal six-sided.

Staurolite $\left(\mathrm{Fe}^{2+}{ }_{2} \mathrm{Al}_{9} \mathrm{O}_{6}\right)\left(\mathrm{SiO}_{4}\right)_{4}(\mathrm{O}, \mathrm{OH})_{2}$

Staurolite has the highest individual mineral with 2.9 and $1.7 \%$ in fine and very fine sand fractions, respectively. It displays a red brown to black, mostly opaque, neosilicate mineral with a white speak.

\section{Sillimanite $\left(\mathrm{Al}_{2} \mathrm{SiO}_{5}\right)$}

It is found in the studied samples with an average content of 3.6 and $2.8 \%$ in the fine and very fine sand size fractions, respectively (Table 3 ). It has yellowish brown and grayish green crystals. The semi-quantitative chemical analysis of sillimanite indicates low content of $\mathrm{Al}_{2} \mathrm{O}_{3}(30.8 \%)$ and high content of $\mathrm{SiO}_{2}$ $(60.2 \%)$. The increased $\mathrm{K}_{2} \mathrm{O}(7.4 \%)$ content due to partial alteration of sillimanite to muscovite along their margins caused decreasing of $\mathrm{Al}_{2} \mathrm{O}_{3}$ content (Hassan et al., 2009). Table (13) summarized their micro semi-quantitative 
Table 13: EDX micro chemical analysis of sillimanite

\begin{tabular}{lr}
\hline Oxide \% & Sillimanite \\
\hline $\mathrm{SiO}_{2}$ & 60.2 \\
$\mathrm{Al}_{2} \mathrm{O}_{3}$ & 30.8 \\
$\mathrm{~K}_{2} \mathrm{O}$ & 7.4 \\
Total & 98.4 \\
\hline
\end{tabular}

chemical analyses of sillimanite.

Tourmaline ( $\mathrm{Na}, \mathrm{Ca})\left(\mathrm{Mg}, \mathrm{Li}, \mathrm{Al}, \mathrm{Fe}^{2+}\right)_{3} \mathrm{Al}_{6}$ $\left(\mathrm{BO}_{3}\right)_{3} \mathrm{Si}_{6} \mathrm{O}_{18}(\mathrm{OH})_{4}$

It is usually brown in colour (sometimes greenish) or brownish yellow and commonly euhedral in shape. It is found in the studied samples with an average content of 0.9 and $0.6 \%$ in the fine and very fine sand size fractions, respectively (Table 3 ). The recorded tourmaline may be derived from rocks associated with the biotite schist along contacts with gneissose granites; amphibolitic rocks closely to Nugrus thrust zones; or from contact between metapelitic schist and leucogranite; and schist in contact aureoles with leucogranite and pegmatite veins (Henry and Dutrow, 1990 \& 1992 and Harraz and El Sharkawy, 2001).

\section{Field Spectrometry}

Field spectrometry survey for the radio- active elements including total count (Ur), uranium (eU), thorium (eTh) and potassium $(\mathrm{K} \%)$ are measured in the studied stream sediments using portable $\gamma$-ray method.

Accordingly, weak radioactivity was recorded in the studied wadi sediments (Table 14). Figure (17) illustrates the lateral distribution between eU and eTh along Wadi Hangalyia and shows slightly increases toward the downstream direction. This may be attributed to two reasons, the first is the change of the background radioactivity due to the change of the hinterland rock units and the second is that hinterland may be hosting radioactive mineralization (i.e. mineralized shear zone of Gabal Nugrus younger granites). Acces-

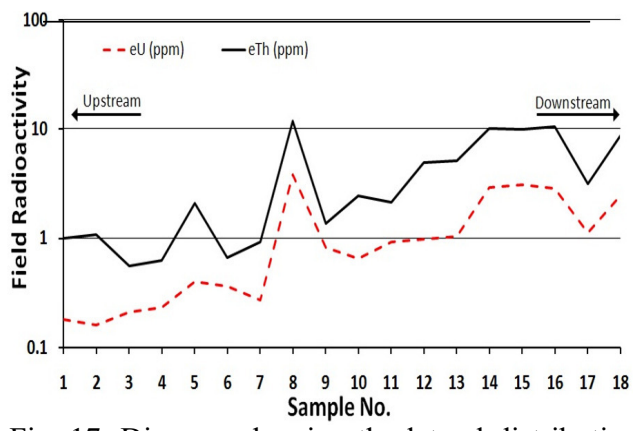

Fig. 17: Diagram showing the lateral distribution of eU and eTh, Wadi Hangaliya stream sediments

Table 14: Spectrometric field measurements of total count, uranium, thorium and potassium and some radioactive ratios $(\mathrm{eTh} / \mathrm{eU}$, eU/eTh and $\mathrm{eTh} / \mathrm{K})$ compared with heavy mineral (\%) of fine and very fine sand sized of W. Hangaliya stream sediments

\begin{tabular}{|c|c|c|c|c|c|c|c|c|c|}
\hline S. No. & TC $(\mu \mathbf{R})$ eL & ppm) & eTh (ppm) & $\mathbf{K} \%$ & eTh/eU & eU/eTh & eTh/K' & Fine $\overline{s a n d}$ & $\begin{array}{l}\text { al heavy_(\%) } \\
\text { v.fine sand }\end{array}$ \\
\hline$\overline{1}$ & 1.87 & $\mathbf{0 . 1 8}$ & 1.00 & 0.38 & 5.56 & 1.8 & $2.63_{1}$ & 2.71 & 0.85 \\
\hline 2 & 2.11 & 0.16 & 1.09 & 0.32 & 6.81 & 1.15 & 3.41! & 3.20 & 1.13 \\
\hline 3 & 1.64 & 0.21 & 0.56 & 0.25 & 2.67 & 0.38 & 2.24, & 2.56 & 1.81 \\
\hline 4 & 3.24 & 0.23 & 0.63 & 0.44 & 2.74 & 0.37 & 1.43! & 4.65 & 1.05 \\
\hline 5 & 2.80 & 0.40 & 2.11 & 0.29 & 5.28 & 0.19 & 7.28 & 2.73 & 0.97 \\
\hline 6 & 1.98 & 0.36 & 0.67 & 0.34 & 1.86 & 0.54 & 1.97! & 5.16 & 2.36 \\
\hline 7 & 3.15 & 0.27 & 0.92 & 0.46 & 3.41 & 0.29 & 2, & 4.12 & 1.45 \\
\hline 8 & 19.60 & 3.82 & 11.77 & 2.89 & 3.08 & 0.33 & 4.07i & 5.68 & 2.77 \\
\hline 9 & 4.93 & 0.82 & 1.36 & 0.49 & 1.69 & 0.6 & $2.78_{1}^{\prime}$ & 4.29 & 3.12 \\
\hline 10 & 3.49 & 0.65 & 2.46 & 0.80 & 3.79 & 0.26 & 3.08 & 7.37 & 2.31 \\
\hline 11 & 5.62 & 0.92 & 2.14 & 0.73 & 2.33 & 0.43 & 2.93i, & 6.32 & 2.55 \\
\hline 12 & 5.22 & 0.97 & 4.94 & 0.91 & 5.09 & 0.2 & $5.43^{\prime}$ & 8.73 & 2.89 \\
\hline 13 & 4.69 & 1.03 & 5.12 & 0.77 & 4.97 & 0.2 & 6.65 & 8.77 & 3.57 \\
\hline 14 & 17.36 & 2.91 & 10.04 & 2.79 & 3.45 & 0.29 & 3.6 & 7.93 & 3.02 \\
\hline 15 & 13.33 & 3.06 & 9.81 & 3.03 & 3.21 & 0.31 & 3.24, & 6.37 & 2.73 \\
\hline 16 & 14.82 & 2.85 & 10.41 & 3.21 & 3.65 & 0.28 & $3.24 i$ & 8.36 & 2.99 \\
\hline 17 & 5.87 & 1.11 & 3.16 & 2.02 & 2.85 & 0.35 & 1.56 & 7.22 & 3.32 \\
\hline 18 & 10.51 & 2.43 & 8.71 & 3.06 & 3.58 & 0.28 & $2.85^{i}$ & 8.53 & 3.06 \\
\hline Average & 6.80 & 1.24 & 4.27 & 1.29 & 3.67 & 0.46 & $3.36 i$ & 5.82 & 2.33 \\
\hline
\end{tabular}


sory minerals hosting radioactive elements in the mineralized shear zone of Gabal Nugrus had been recorded by many authors; El Feky (2000), El Feky et al. (2004) and Raslan and Ali, (2010).

El Meliegy et al. (1999) divided the hinterland cut by Wadi Hangaliya to three units according to their aeroradiometric data. The first unit had a total count range between 1.6 and $7.1 \mathrm{Ur}$ with arithmetic mean of 5.0 Ur. The second unit had a greater values range between 7.3 and $10.5 \mathrm{Ur}$ with arithmetic mean of 8.7 Ur. Finally, the third unit had greater values range between 13 and $22.7 \mathrm{Ur}$ with arithmetic mean of 15.7 Ur. The prior one attributed to metavolcanics and mafic rock units, while the later two were attributed to younger granite of Gabal Nugrus. These data agree with the ground spectrometry of present work in Wadi Hangaliya (Table 14). The maximum total count was $19.6 \mathrm{Ur}$ which recorded in station No. 8 at outlet of small khour derived directly from Gabal Nugrus granitic pluton. On the other hand, the minimum total count was $1.64 \mathrm{Ur}$ that recorded at station No. 3 laying in main course of Wadi Hangaliya eastern extremity which cut the metavolcanics and mafic rocks.

The close association of uranium and thorium in minerals and rocks can be explained by their similarity in their charge and ionic radii. Uranium is more active than thorium thus $\mathrm{U}$ easily mobilized and migrates under oxidation conditions of underground and rainwater while $\mathrm{Th}$ is relatively stable in the oxidation zone and stay in place. Theoretically, the original expected U-content is calculated by dividing eTh-content by the average crustal eTh/eU ratio in granites $(3-4)$. (Clark et al., 1966).

Generally, Th is occurring as three times as uranium in abundance of the stream sediments and rocks (Chatterjee and Muecke, 1982). Variation in eTh/eU ratios (Table 14 and Figs. 18-22) of the present work indicates depletion or enrichment of uranium in the stream sediments. Wadi Hangaliya sam- ples have eTh/eU ratio ranges from 1.69 to 6.81 with average of 3.67 (Table 14) indicating the enrichment of thorium and mild leaching of uranium in their stream sediments.

The lowering uranium value may be due to the nature of Wadi Hangaliya sediments, whereas the area under study fall in the arid region of Egypt (Table 14). The annual rainfall is about few millimeters per year. Sometimes dry season continuous to seven years; the only water supply in that dry seasons is the air moisture. The water table in the wadi is about 20 meters under the wadi level according to field measurements in nearby water well shown on Fig.1a. So, the expecting of wide uranium migration in those arid conditions is not logic.

A stronge positive value of correlation coffecient $(\mathrm{r}=0.9)$ was computed between $\mathrm{eU}$ and eTh and clearly illustrated on Fig. 17. Those values suggest that both uranium and thorium (Fig. 18) occur in U- and Th-bearing accessory minerals. This may be explained by their tendency to crystallize during the late stages of the magmatic differentiation of the source area (Raslan and Ali, 2010), permitting uranium and thorium to inter the internal structure of the resistant accessory heavy minerals such as zircon, monazite, sphene and apatite. The more differentiated rocks have the highest eU/eTh ratio and greater uranium content (Chatterjee and Muecke, 1982).

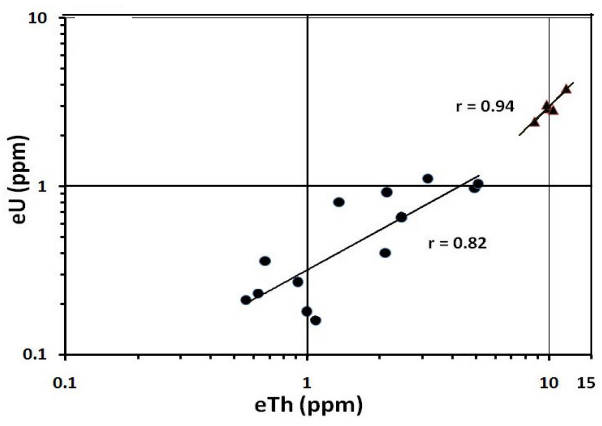

Fig. 18: Binary diagram showing eU vs. eTh of Wadi Hangaliya stream sediments 
Figures (19-21) show opposite correlation between the two types of correlated sediments, i.e. sediments derived from felsic rocks related to Gabal Nugrus younger granites and sediments derived from mafic rocks which related to metavolcanics and serpintinites. The possible explanation of the opposite slopes is source rock of the sediments and/or mineral stability is another factor to consider (Scheidt, 1975).

Statistical analysis of the obtained minerological total heavy $\%$ of the sand size factions and radiometric data (expresed in total count and some ratios) of the studied samples (Fig. 22) shows opposite correlation between the two types of correlated sediments.

Many major minerals in igneous rock contain ${ }^{40} \mathrm{~K}$ and some supported ${ }^{230} \mathrm{Th}$. Potassium feldspar and micas are usually high in ${ }^{40} \mathrm{~K}$ (Scheidt, 1975). The potassium radioactivity component of stream sediments is explained by the potassium feldspar content (Force et al., 1982). The variations of Wadi Hangaliya (Figs. 18-23) illustrate that the potassium content in the deposits derived from youngest granitoids (Gabal Nugrus) being greater than the deposits derived from older origin (mafic, ultramafic and metavolcanic rocks). Mica is also present in Wadi Hangaliya stream sediments and contributes

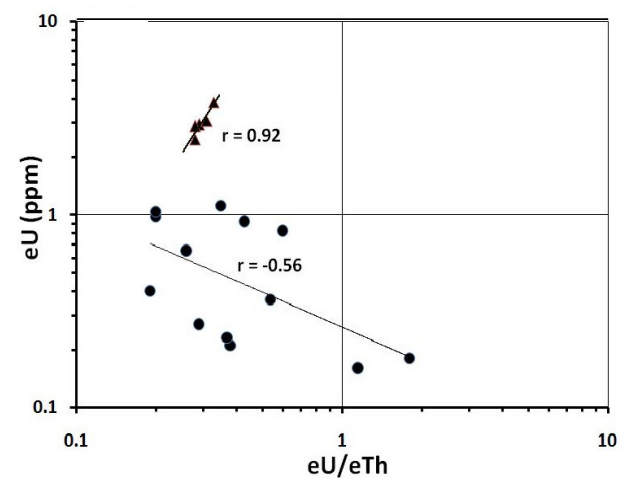

Fig. 19: Binary diagram showing eTh vs. eU/eTh of Wadi Hangaliya stream sediments

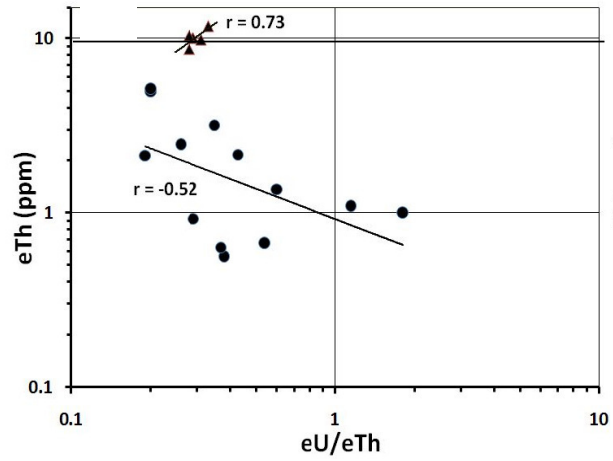

Fig. 20 : Binary diagram showing eU vs. $\mathrm{K}$ of Wadi Hangaliya stream sediments

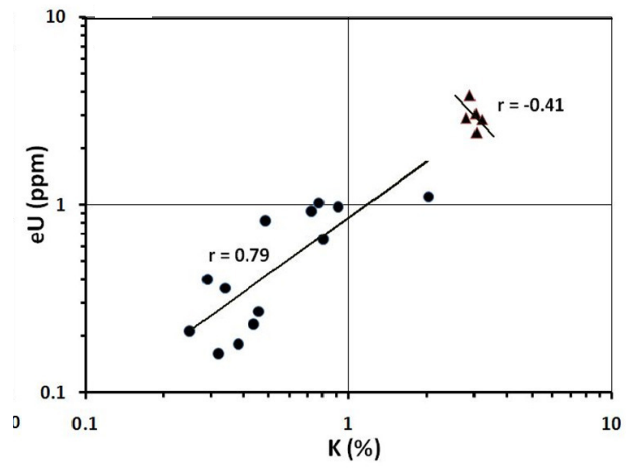

Fig. 21: Binary diagram showing eTh vs. K (e) of Wadi Hangaliya stream sediments

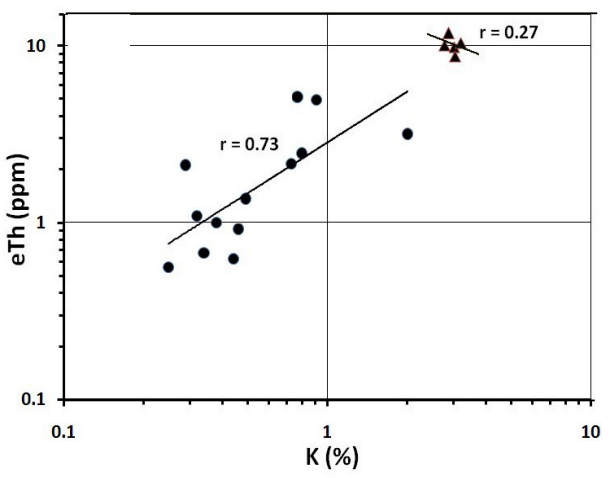

Fig. 22: Binary diagram showing $\mathrm{eTh} / \mathrm{K}$ vs. total heavy (\%) of fine sand fraction of Wadi Hangaliya stream sediments 
to the potassium component of radioactivity. Mica is belonging to the light fraction and its abundance was not established because of counting difficulties. The clay fraction in the wadi is very small due to immaturity of the sediments. Illite (K-bearing mineral) forms only a minor part of the clay minerals (Scheidt, 1975); thus, potassium-bearing clay could not possibly affect the radioactivity of Wadi Hangaliya deposits.

$\mathrm{eTh} / \mathrm{K}$ ratio plotted against the total heavy mineral should more accurately represent detrital mineral-radioactivity relationships (Scheidt, 1975).

$\mathrm{e} \mathrm{Th} / \mathrm{K}$ ratio show that it is highly correlated with the total heavy mineral \% in Wadi Hangaliya sediments (Fig. 23). In resistant minerals eTh is supported by eU. Abundances
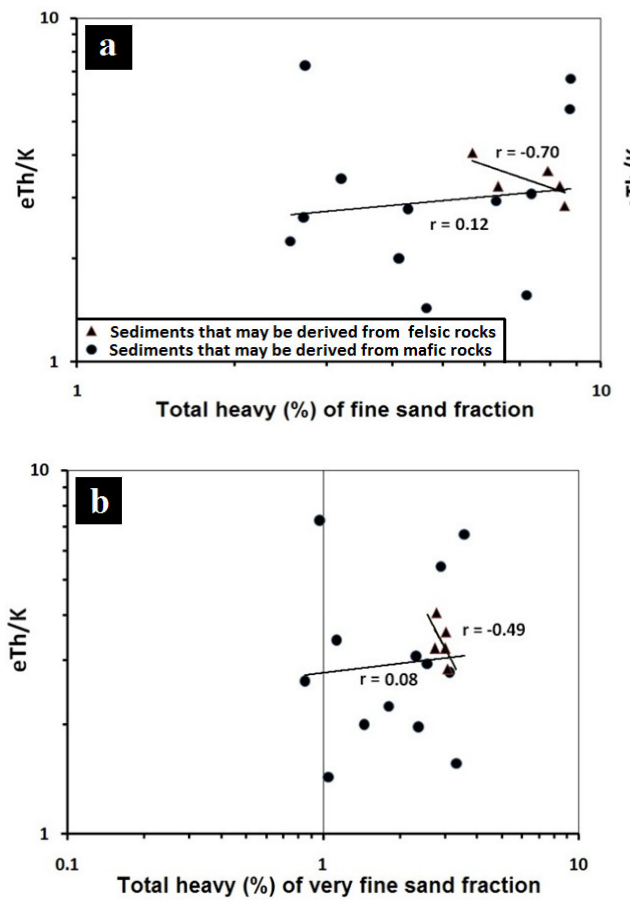

Fig. 23: Binary diagrams showing total heavy (\%) of very fine sand fraction of Wadi Hangaliya stream sediments of eU and eTh in accessory resistant minerals are affected by such factors as variation in concentration in the original magma and in the magmatic crystallization history.

Distribution of K shows opposite tendencies to distribution of eTh and heavy mineral. These trends are seen on Fig.23. Generally, high $\mathrm{K}$ radioactivity is found in areas high in mud content and low in heavy mineral. Medium $\mathrm{K}$ radioactivity was associated with sandy sediments. Sandy sediments, particularly those high in heavy minerals are also high in eTh (Scheidt, 1975).

\section{CONCLUSIONS}

Studied stream sediments in both fine and very fine sand size fractions show a moderate content of Fe-Ti oxides, rutile, zircon, staurolite, sillimanite, titanite, barite and epidotes, whereas amphiboles, pyroxenes, tourmaline, garnet, monazite and thorite are much lesser. The total heavy mineral percentage in the fine sand fraction has average content of 5.82, while it decreases in the very fine sand size fraction that has an average content of 2.33.

Primarily estimation of visible gold average content of Wadi Hangaliya uses wet tabling panning technique for fractions $<0.250$ $\mathrm{mm}$. Seventy three percent of the studied samples are Au-bearing with an average content of $1.135 \mathrm{~g} /$ ton Au. The maximum recorded gold content reaches up to 4.141 $\mathrm{g} /$ ton $\mathrm{Au}$. The gold content may increase in case of use fire assay which deals with the bulk sample including the invisible gold mineralization and grain size higher than 0.250 $\mathrm{mm}$. The source rock, relief and mechanical weathering are the main controlling factors in the development of these arid environment gold placers.

The ground spectrometric survey showed that radioactivity of Wadi Hangaliya stream sediments increases toward the west direction and ranged in their total count from 1.64 to $19.60 \mu \mathrm{R}$ toward the downstream of the main wadi. This may be attributed to the fact 
that the Wadi Hangaliya cut throw weak radioactive source rocks of metavolcanics and serpintinites, expect in its western extremity, where the wadi cut through younger granites of Gabal Nugrus. The weak radioactivity of Wadi Hangaliya makes it suitable for gold extraction field industry.

\section{REFERENCES}

Antweiler, J. C., and Love, J. D.,1967. Gold-bearing sedimentary rocks in northwest Wyoming a preliminary report. U.S. Geol. Surv. Circular, 541, 12 p.

Basyoni, M. H., and Surour, A. A., 2006. Sedimentology and economic potentialities of the Red Sea coastal sediments at Umm Lajj area, Saudi Arabia. Final Report of Project no. 201/425 funded by Institute of Research and Consultation (IRC), King Abdulaziz Univ., Jeddah.

Chatterjee, A. K., and Muecke, G. K.,1982. Geochemistry and the distribution of uranium and thorium in the granitoids rocks of the South Mountain Batholith, Nova Scotia: some genetic and exploration implications. In: uranium in granites (Mourice, Y. T., Ed.). Geol. Surv. Canada, Ottawa, Paper 81-23, 11 - 17.

Clarke, S. P. Jr; Peterman, Z. E., and Heier, K. S., 1966. Abundances in uranium, thorium and potassium. In: Handbook of physical constants. Geol. Soc. America, Memoir 97, 521 - 541.

CONCO Coral,1987. Geological map of Egypt, scale 1:500,000. NG 36 SE, Gabal Hamata. The Egyptian General Petroleum Corporation, Cairo (EGPC), Egypt.

El Bayoumi, R.M.A., and Greiling, R.O., 1984. Tectonic evolution of a Pan-African plate margin in southeastern Egypt - a suture zone overprinted by low angle thrusting. In: African Geology ( Klerkx, J.,\& Michot, J., Eds.). Tervuren, Belgium, 47-56.

El Feky, M. G.,2000. Geology, geochemistry and radioactivity of Wadi Hangalyia area. South Eastern Desert. Ph. D. Thesis, Cairo Univ., Egypt, 290 p.
El Feky, M. G.; Abd El Waeith, A., and Ali, B. H., 2004. Geochemistry of mineralized granities of G. Ngrus, south Eastern Desert, Egypt. Delta. J. Sci., 28, 117 - 133.

El Gaby, S.; List, F. K., and Tehrani, R., 1988. Geology, evolution and metallogenesis of the Pan-African Belt in Egypt. In: The Pan-African Belt of Northeast Africa and Adjacent Area (El Gaby, S.,\& Greiling, R.O., Eds.). Friedr Viewegsohn, Braunschweig, $17-68$.

El Meliegy, M. A.; Hassanein, H. I., and Kamel, A. F., 1999. Integrated geological and geophysical study for exploration of radioactive mineral occurrences, Gabal Nugrus-Gabal Sekeit area, Southern Eastern Desert, Egypt. Proc. Egypt. Acad. Sci., 49, 105 - 127.

El Ramly, M.F., 1988. Geologic map of Egypt, scale 1:100,000. Wadi Hafafit area.

El Ramly, M.F.; Greiling R.O.; Kröner A., and Rashwan A. A., 1993. On the tectonic evolution of the Wadi Hafafit area and environs EDE. Bull. Fac. Earth Sci. King Abdulaziz Univ., 6, 113 - 126.

English, B.L.; Desborough, G.A., and Raymond, W. H.,1987. A Mechanical panning technique for separation of fine-grained gold and other heavy minerals. U.S. Department of the Interior Geological Survey. Open-File Report, 870364.

Farid, A. A., 2005. Evaluation and mineral processing of some economic minerals in $\mathrm{El} \mathrm{Bu}$ rullus- Baltim sand dunes, Nile Delta, Egypt. Unpublished Ph. D. Thesis, Mansoura Univ., 205p.

Folk, R.L., and Ward, W.C.,1957. Brazos river bar: a study in the significance of grain size parameters. J. Sediment. Petrol., 27, 3 - 26.

Force, E. R.; Grosz, A.E.; Loferski, P. J., and Maybin, A.H., 1982. Aeroradioactivity maps in heavy-mineral exploration Charleston, South Carolina area. Geol. Surv. Prof. pape., No. P1218, 19 p.

Google earth, 2012. Updated satellite images of 
the Earth Planet from the internet site. www. Googleearth.com.

Greiling, R.O. ,1990. Structural Geology map of Egypt, scale 1:100,000. Wadi Hafafit area.

Harraz, H.Z., and El-Sharkawy, M.F.,2001. Origin of tourmaline in the metamorphosed Sikait pelitic belt, south Eastern Desert, Egypt. J. Afr. Earth Sci., 33, No. 2, 391-416.

Hassaan, M.M.; El-Mezayen, A.M.; Ramadan, T. M.; Abd El-Rahman, M.K.; Hassan, M.S., and El-Desoky, H.M.,2009. Upgrading of Sillimanite and Garnet Ores to Improve Their World Market Competitiveness. Ausralian J. Basic and Appl. Sci., 3(2), 371-384,

Henry, D.J., and Dutrow, B.L.,1990. Ca substitution in Li-poor aluminous tourmaline. Canadian Mineralogist, 28, 111-1 24.

Henry, D.J., and Dutrow, B. L., 1992. Tourmaline in a low grade clastic metasedimentary rock: an example of the petrogenetic potential of tourmaline. Contributions Mineralogy Petrology, 112, 203-218.

Khalil, K.I., and Helba, H.A.,1998. Gold mineralization and its alteration zones at Hangaliya gold mine, Eastern Desert Egypt. The $10^{\text {th }}$ Ann. Meet. Mineral. Soc. Egypt. 4 (Abstract).

Lyakhovich, T.T., and Lyakhovich, V.V. , 1983. New data on accessory mineral compositions. Geochem. Intr., 20, No. 6, 69 - 100.

Moufti, A.M.B.,2009. Mineralogy and mineral chemistry of auriferous stream sediments from Al Wajh area, NW Saudi Arabia. Arab J. Geosci., 2, 1-17.

Raslan, M.F., and Ali, M.A., 2010. Mineral chemistry of polymetallic mineralization associated with altered granite, Hangaliya area, South Eastern Desert, Egypt. GEOLOGIJA, 53/2, $129-138$.

Scheidt, R.C.,1975. Relation between natural radioactivity in sediment and potential heavy mineral enrichment on the Washington continental shelf. M. Sc. Thesis, Oregon State Univ., 64 p.

Strakhov, N.M.; Bushinskii, G.I., and Pustovalov, L.V.,1957. Metody izocheniya ocadochnykh porod, tom I" (Methods of studying sedimentary rocks, vol. I). Moskva, Gosgeoitekhiz dat, $611 \mathrm{p}$.

Surour, A.A.; El Bayoumi, R.M.; Attawiya, M. Y., and El Feky, M.G., 2001. Geochemistry of wall rock alterations and radioactive mineralization in the vicinity of Hangaliya uraniferous shear zone, Eastern Desert, Egypt. Egyp. J. Geol., 45/1, 187-212.

Surour, A.A.; El Kammar, A.A.; Arafa, E.H.,and Korany, H.M., 2003. Dahab stream sediments, southeastern Sinai, Egypt; a potential source of gold, magnetite and zircon. J. Geochem. Expl., $77,25-43$.

Taggart, A.F., 1956. Handbook of mineral dressing: ores and industrial minerals. New York, Columbia Univ., sixth printing, 11-12.$$
\text { معدنية وإشعاعية رواسب وادي حنجلية، جنوب الصحراء الثرقية، مصر }
$$$$
\text { جهاد محمد رضا منصور، عبد العليم عبد العليم أبو دياب و أنس ماللك الثريف }
$$$$
\text { يلقي هذا البحث الضوء علي الخصائص المعدنية و الاشعاعية لرواسب وادي حنجلية الذي يجري بالمنطقةً القاحلةً }
$$

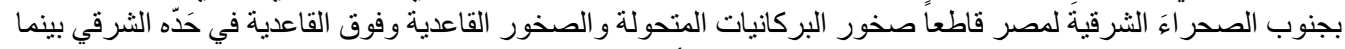

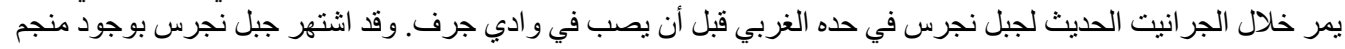$$
\text { فرعوني للذهب. }
$$$$
\text { تم تجميع عدد 1 } 1 \text { عينة من رواسب الو ادى وجهزت معملياً لفصل المعادن الثقيلة وتحديدها وتعبين نسب تركيز ها }
$$

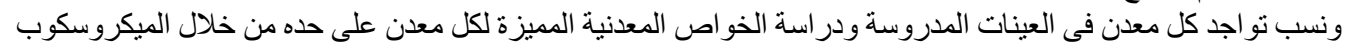




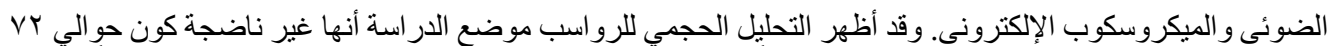

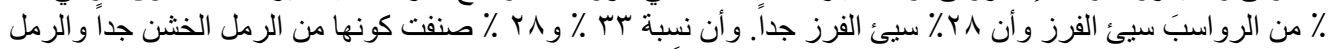

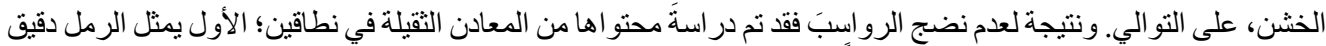

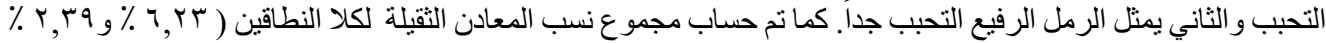

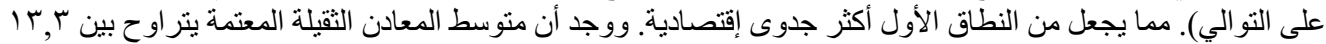

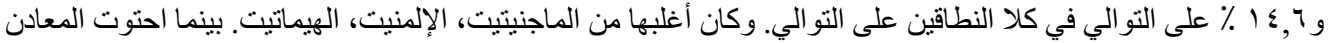
غير المعتمة لكلا النطاقين على معادن الزركون المشع، الأباتيت، التينانيت، السليمنيت، الثتروليت، الرونيل، الجارنت،

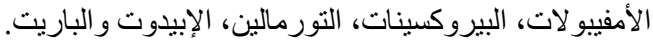

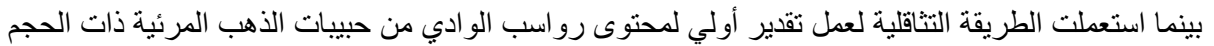

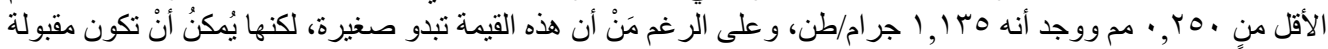

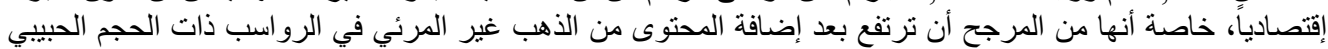

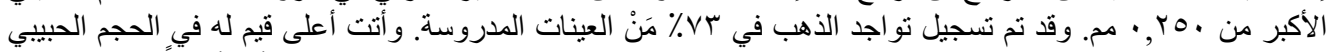

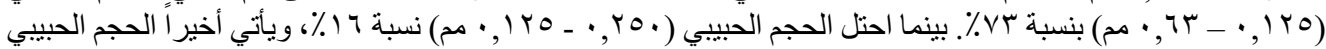

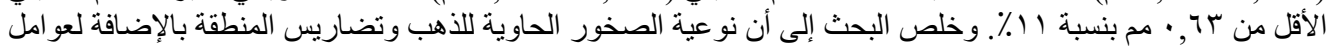

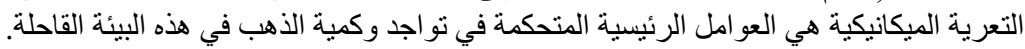

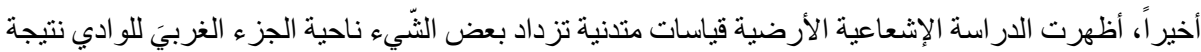

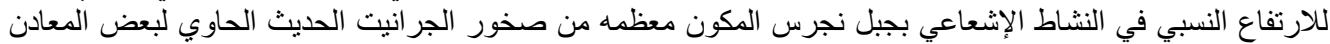

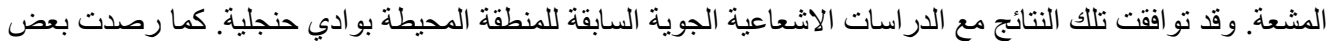

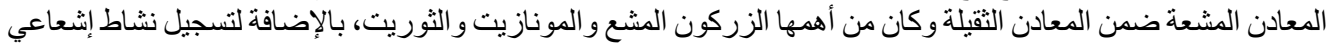

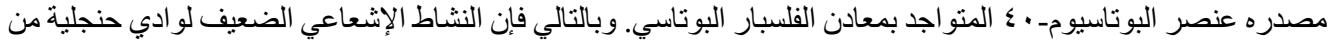

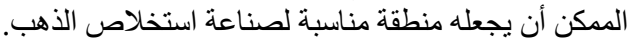

